Article

\title{
Representing 'Place': City Climate Commissions and the Institutionalisation of Experimental Governance in Edinburgh
}

\author{
Alice Creasy ${ }^{1, *}$, Matthew Lane ${ }^{1}$, Alice Owen ${ }^{2}$, Candice Howarth ${ }^{3}$ and Dan van der Horst ${ }^{1}$ \\ ${ }^{1}$ School of GeoSciences, University of Edinburgh, Edinburgh, EH8 9XP, UK; E-Mails: alice.creasy@ed.ac.uk (A.C.), \\ matthew.lane@ed.ac.uk (M.L.), dan.vanderhorst@ed.ac.uk (D.v.d.H.) \\ 2 School of Earth and Environment, University of Leeds, Leeds, LS2 9JT, UK; E-Mail: a.m.owen@leeds.ac.uk \\ ${ }^{3}$ Grantham Research Institute on Climate Change, London School of Economics and Political Science, London, WC2A 2AE, \\ UK; E-Mail: c.howarth@Ise.ac.uk \\ * Corresponding author
}

Submitted: 29 October 2020 | Accepted: 18 January 2021 | Published: 28 April 2021

\begin{abstract}
Against the backdrop of increasingly fragmented and poly-centric urban climate governance, this article examines the establishment of city climate 'commissions' as an experimental means of addressing the challenge of climate change at the city-scale. In doing so it addresses the question: What constitutes diversity in voices and perspectives when trying to represent the city as a place for climate action? To answer this question, the article presents an analysis of the Edinburgh Climate Commission's establishment, drawing on participatory ethnographic research carried out by a researcher embedded within the project team. The account of how this new mode of urban governance was both conceptualised and then put into practice offers a new institutional angle to the literature on urban 'experimentation.' Through our reflective analysis we argue that aspirations to ensure pre-defined 'key' industries (high carbon emitters) are accounted for in commissioner recruitment, and an over-emphasis on capturing discernible 'impacts' in the short term (by involving organisations already pro-active in sustainable development) hindered an opportunity to embrace new perspectives on urban futures and harness the innovative potential of cities to engage with the multifaceted nature of the climate challenge. Furthermore, new insight into the relationship between local authorities and other 'place-based' agents of change opens up important questions regarding how to balance the attainment of legitimacy within the political status quo, and the prospect of a new radical politics for urban transformation.
\end{abstract}

\section{Keywords}

agency; cities; climate change; Edinburgh; local governance; net zero; polycentrism; Scotland

\section{Issue}

This article is part of the issue "Is There a New Climate Politics? Emergency, Engagement and Justice" edited by Anna R. Davies (Trinity College Dublin, Ireland), Stephan Hügel (Trinity College Dublin, Ireland) and Vanesa Castán Broto (University of Sheffield, UK).

(C) 2021 by the authors; licensee Cogitatio (Lisbon, Portugal). This article is licensed under a Creative Commons Attribution 4.0 International License (CC BY).

\section{Introduction}

While the traditional view of governance is that of local political action shaped by national policy-making and international agreements (Anguelovski \& Carmin, 2011), in recent years cities have been increasingly promoted as 'strategic arenas' for experimentation when it comes to the governance of climate change (Castán Broto, 2020).
This localisation of a planetary sustainability agenda has raised a number of questions regarding how underresourced and over-burdened local governments can be supported and empowered to drive forward change in an increasingly polycentric landscape of climate governance (Jordan et al., 2015). While this interest in urban centres is often draped in terminology of 'devolution,' 'ownership' and 'autonomy,' it does so against a backdrop of 
decades of neoliberal agenda-setting which has reduced urban governance to a practice of inter-city competition as local authorities compete with each other for an ever-shrinking pool of resources (Davidson \& Iveson, 2015; Harvey, 1989; Mouffe, 2005). As a result, to date the question of climate change as an explicit agenda for the local scale has, inevitably, taken on a somewhat experimental form involving a range of place-based private, public and civil society stakeholders operating in and between fragmented formal governance landscapes (Caprotti \& Cowley, 2017; Dikeç \& Swyngedouw, 2017; Fudge \& Peters, 2009; Stripple \& Bulkeley, 2019).

Such a complex and constantly changing landscape presents urban stakeholders interested in addressing climate change with both challenges and opportunities. On the one hand, there is a considerable risk of undermining local democracy by depoliticizing decisionmaking in the city through the unanticipated devolution of responsibility to a series of unelected actors setting their own agendas (Davidson \& Iveson, 2015; Hodson \& Marvin, 2010; Karaliotas \& Bettini, 2016). However, while the de-politicisation of urban governance is certainly a recognised trend, some have argued that this experimentation may in fact lead to more effective and innovative forms of decision-making materialising at previously unharnessed scales (Hughes, Chu, \& Mason, 2018; Romero-Lankao et al., 2018). One such argument is about the opportunity this opens up for non-state local actors to bring their diverse resources to bear on pressing governance challenges. Actors such as universities (deeply embedded in the places in which they are located and therefore with a vested interest in the effects and impacts of a changing climate on their cities) can take on 'place-based' leadership roles in the forging of new modes of local governance (Vallance, Tewdwr-Jones, \& Kempton, 2019). In taking on such roles, an opportunity also exists to diversify the perspectives on sustainability problems brought to the tables of governance and to redistribute power across a broader network of actors invested (physically, economically, and emotionally) in particular places. This could, in turn, allow for responses to calls from a variety of scholars for a decolonisation of the knowledge bases which continue to myopically frame society's principal challenges (Braun, 2002; Quijano, 2000; Santos, 2008; Vainer, 2014).

Reflecting on an opportunity to deliver place-based experimental leadership in practice, this article draws from an ethnographic case study observing the establishment of the Edinburgh Climate Commission (henceforth 'the Commission') and its introduction into the city's political and institutional fabric. Delivered as part of a UK-wide network of city-level commissions premised on facilitating cross-sector collaboration within the city, the Commission presented an experimental opportunity to establish a new institutional entity with a mandate to coordinate action on climate change alongside the local authority. Developed in partnership between the University of Edinburgh and the City of Edinburgh
Council, this innovative mode of urban climate governance offers a potential mechanism for greater action on climate change by more effectively harnessing the local resource bases of a variety of stakeholders, and allowing them to find a more coordinated expression.

Through engagement with an ethnographic account of decision making and the drivers and logics behind these decisions as they played out during the setting up of the Commission, we ask: What constitutes diversity in voices and perspectives when trying to represent the city as a place for climate action? In asking this question we seek to understand which agencies, described by Ramirez, Estevez, Goyeneche, and Rodriguez (2020) as being 'embedded' in the intimate interactions of placebased coalitions and capable of driving change, can be sought out and harnessed in pursuit of action on climate change at the city-scale. We are also interested in how what Castán Broto (2020) describes as the situated 'messiness' of pre-existing climate change governance (comprising a variety of actors and agents operating across various geographical and institutional scales) is navigated when attempting to establish political and institutional legitimacy beyond the local state.

In addition to critically reflecting on this novel mode of local climate governance, our theoretical aspirations are animated by a desire to better understand the 'places' to which 'place-based' governance arrangements come to represent. Barron, Hartman, and Hagemann (2020) observe that the complexity of place in relation to sustainability and climate change remains remarkably under-theorised. This is despite its increasing prevalence within both political ('place-making') and societal ('sense of place') discourse. Sustainability, they argue, continues to be seen as a framework for neoliberal development whose focus on issue-based policies fails to recognise the "particularities of individual places, the people and organisms that inhabit them, and the ways in which they interact with other places" (Barron et al., 2020, p. 448). Taking our inspiration from this critical (re-)engagement with the importance of place, in this article we seek to analyse the way in which a shift to ostensibly 'place-based' local governance arrangements grapples with these multiplicities in pursuit of action on climate change.

The article's contributions are developed over three further sections. The following section introduces the case study and describes our methodological approach to empirical research, ethnographically embedded within decision making around the establishment of the Commission as a new mode of urban climate governance. This section also includes reflections on how the ideas of geographer Doreen Massey (2004) were drawn upon to develop an interpretive framework for making sense of the ethnographic material. The subsequent section then presents an account of how the city of Edinburgh was first framed as a place in need of a new (and explicit) mode of climate change governance requiring leadership from more than just the city 
council. It subsequently discusses how this interpretation of 'place' came to be represented by a very particular set of stakeholders deemed to have the requisite capacity to deliver on this new governance mandate. The concluding discussion then unpacks the implications of this for how the city of Edinburgh continues to be imagined as a place for taking action on climate change and reflects on the need for a more attentive approach to the question of what climate commissions can be visà-vis existing urban governance institutions. For other cities looking to establish place-based climate commissions, we suggest there is an opportunity to reflect on how greater attention to the complexity of 'place' might open up and diversify (rather than impede and decelerate) local action on climate change.

\section{Case Study and Methodology}

\subsection{The Commission}

The Commission was established in February 2020. It has been conceptualised and delivered through the PlaceBased Climate Action Network (PCAN); a multi-university led project funded by the UK's Economic and Social Research Council. As part of its networked approach to driving place-based action on climate change, PCAN aims to establish climate 'Commissions' as replicable, local models of climate change governance that foster cross-sector collaboration between public, private and third sector organisations operating in specific locations (PCAN, 2019). PCAN's aspiration for a replicable model of urban climate governance goes beyond mere learning and knowledge exchange aspirations, setting it apart from other inter-city networks operating in a similar thematic space, such as C40 cities and the UK100 programme. Initially focused on three core city-based Commissions in Belfast, Leeds and Edinburgh, the network continues to expand and incorporate additional cities, towns and counties including Lincoln, Doncaster, Croydon and Surrey. Within the context of the PCAN project, climate commissions are defined as:

City or area-wide partnerships bringing together people and organisations from the public, private and civic sectors who work collaboratively to help drive, guide, support and track climate action. Commissions are independent bodies that complement the activities of local government, combined authorities and local enterprise partnerships and that extend their reach and build an area's capacities to deliver climate resilience and low carbon transitions. (PCAN, 2019)

The Commission has been co-sponsored by the University of Edinburgh and the City of Edinburgh Council, who jointly serve as the secretariat for the Commission. Officers from the Council's Policy and Insight Team and members of the University's Centre for Carbon Innovation worked together closely in order to set up the Commission, select its members, and envisage a strategy and workplan. The chosen members of the Commission cover a range of industries across the private, public and third sectors (Table 1 ). In terms of the Commission's governance the most influential member is the Chair who, having been identified early in the process, also oversaw the recruitment of commission members.

Table 1. The sectoral background of the members of the Commission.

\begin{tabular}{ll}
\hline Role on the Commission & Employment \\
\hline Chair & Head of Climate Change \& Sustainability at energy supply company \\
Vice-Chair & Leader of City of Edinburgh Council \\
Member & Chief Executive at a local community support hub \\
Member & Chief Executive at a local environmental NGO specialising in Energy and fuel poverty, \\
recycling and carbon reduction
\end{tabular}




\subsection{Methodology}

The empirical data was collected by the lead author who, as an MSc student and voluntary project ethnographer (for her dissertation) was able to closely follow the process of setting up and establishing the Commission. From its initial conceptualisation as part of the PCAN project (2019), through discussions with other member cities in the network, to the selection and recruitment of Commission members in Edinburgh, the lead author was able to observe how decisions were made, by whom, and based on which logics. The aim of the empirical engagement was thus to chart comprehensively how a new mode of urban climate governance came into being, how it interacted with what already existed within the political and institutional fabric of the city, and what ultimately materialised as a result of these interactions.

Data was principally collected via an ethnographic field diary, with entries collated between October 2019 and May 2020. This diary was used to note down observations, quotes from meetings, immediate post-interview thoughts and self-refection (Emerson, Fretz, \& Shaw, 2011). A process of sustained participant observation gave an insight into the changing views of participants and constantly evolving nature of the project (Spradley, 1980). Rather than being a research 'technique,' participant observation is a mode of being-in-the-world embodied by the researcher (Hammersley \& Atkinson, 1983). Fieldnotes were generated from meetings: i) amongst members of the Commission's secretariat, hosted at the University of Edinburgh; ii) the wider PCAN project team from across the UK; and iii) the Commission itself. In addition to this, the researcher also attended (either in person or virtually) meetings of the Policy and Sustainability Committee of Edinburgh City Council, made up of crossparty elected members who would be responsible for defining the commission's relationship with the city's political sphere.

Semi-structured interviews with key individuals involved in the set-up process of the Edinburgh
Commission (see Table 2) were used to supplement the collected ethnographic material (Jacobsen, 2014). A total of 11 interviews were carried out between October 2019 and April 2020 ranging in length from 35 to 75 minutes. The purpose of these interviews was to fill in any gaps in the researcher's understanding of the decision-making rationales at work in setting up the Commission by generating reflective, first-hand accounts from those with powerful roles in the process (Allen, 2017). These interviews should be considered part of (and not separate to) the ethnographic process. The interview questions themselves were driven not only by a desire to better understand and 'join the dots' (Ward, 2018), but also by the researcher's own identity as both a lifelong Edinburgh resident and a passionate urban environmentalist. Identities which served to situate the researcher both 'within and beyond the field' (Mannay \& Morgan, 2015).

The empirical material collected by the above methods provides the basis for the presentation of a critical urban case study (Flyvbjerg, 2006, 2011; Ward, 2018; Webb, 2019). Through this case study, we chart the establishment of the Commission as an exercise in 'institutional bricolage' (Cleaver \& de Koning, 2015). This refers to an approach which views the emergence of new understandings not as a mere assembling of a group of stakeholders, but as a power-laden process which draws on both new and existing place-based agencies. In order to unpick this for the case of the Commission, analysis of the collected material was undertaken via iterative discussions between the ethnographic researcher and wider members of the project team. In this sense, and following Pachirat (2017, p. 148), the ethnographic material is not considered to be some form of extracted 'raw' data "that can then be checked against any 'analysis' in a finished ethnography." Instead, the material offers an interpretive rendering of the world which gives "explicit attention to power relations" (Pachirat, 2017, p. 153) in its attempt to understand how the City of Edinburgh is being understood, defined, and represented by this new institution.

Table 2. List of interviewees: Roles are generalised to some extent for the sake of anonymity.

\begin{tabular}{lll}
\hline Interviewee code & Role in setting up the Commission & Interview length \\
\hline LeedsCC & Leeds Climate Commission Member & 45 minutes \\
LeedsU1 & University of Leeds Project Team & 1 hour \\
LeedsU2 & University of Leeds Project Team & 1 hour \\
LeedsU4 & University of Leeds Project Team & 1 hour 15 minutes \\
EdU1 & University of Edinburgh Project Team & 34 minutes \\
EdU2 & University of Edinburgh Project Team & 45 minutes \\
EdU3 & University of Edinburgh Project Team & 50 minutes \\
EdCouncil1 & Councillor on the Policy and Sustainability Committee & 35 minutes \\
EdCouncil2 & Councillor on the Policy and Sustainability Committee & 1 hour \\
EdCouncil3 & Councillor on the Policy and Sustainability Committee & 1 hour 10 minutes \\
EdCC & Edinburgh Commission Member & 45 minutes \\
\hline
\end{tabular}


Our analysis, played out in these post-fieldwork discussions, sought to 'make sense' of what had been gathered and was guided by the pioneering work of geographer Doreen Massey (2004). For emerging placebased environmental governance practices such as the Commission, while the devolution of responsibility to cities may serve to empower and stimulate action, the notion of 'place' to which this pertains is under constant negotiation and should not be taken for granted, or more explicitly, should not be confused with (or supplemented by) mere "locatedness" (Massey, 2004, p. 8). Massey's arguments regarding the need to make this key distinction have important implications for the establishment of the Commission; a project that is simultaneously embedded in the context of Edinburgh (and therefore striving to account for the unique particularities of this place), while also remaining tethered to a generalizable approach to transferable and reproducible modes of 'place-based' climate governance. In the following sections we therefore use this analysis to present two ethnographic 'tales' (Van Maanen, 2011); narratives which account firstly for the way in which Edinburgh was framed and understood as a place needing to be represented by a climate commission, and secondly for the identification of the individual and collective agencies deemed to have the capacity to deliver this. While the insights generated by the narratives will have wider relevance by virtue of what is revealed regarding the complexity of contemporary urban climate governance, the experimental nature of the project also allows us to position our findings as reflections for other academics engaged with critical social science but also seeking to support impact-oriented projects launching climate commissions or similar new institutional entities. The work presented here should certainly not be read as criticism of the commissioners or take anything away from those who helped to ensure the commission's successful launch during the Covid-19 pandemic. As voluntary project ethnographer, the lead author was formally independent of the PCAN project and thus sufficiently distanced to develop this critique-in collaboration with her dissertation supervisor (second author). Involvement in the write-up of this article has helped the other co-authors who are core members of the PCAN team, to internalise this critique and reflect on the consequences for this project. That important discussion lies beyond the scope and limit of this article.

\section{Findings}

\subsection{Conceptualising a Climate Changing Edinburgh}

We might not get it right from the start...in fact I'm a little bit frustrated right now that it feels like that's the process we've gone through and that we could have just got on with it six months ago. And that's partly to go back to that resourcing and commitment thing, but it's partly just the kind of journey to get everybody to buy into what you're going to do. We didn't get a green light for doing it in partnership with the Council until about October at the Policy and Sustainability Committee meeting and at that point, we thought right, game on. Now here we are in January and we still haven't got a Climate Commission...meanwhile the planet is melting and we're all going to die. (EdU2)

This quote offers an important starting point for understanding the powerful discourses involved in steering the establishment of the Commission and reflects some of the top-down pressures that played a key part in forging how the city came to be understood as a place subject to a new mode of experimental climate governance. These pressures coalesced around three themes at global, national, and local scales: the existential threat of climate change; the mandate put forward by PCAN and other Climate Commissions already established in the network; and the pre-existing approach to climate governance by City of Edinburgh Council and their enrolment into the set-up process. Not only did these pressures form the crucible in which the city came to be interpreted as a place where action could (and then should) be taken on climate change, but they dictated the speed at which the Commission was created, accelerating progress and shaping decision-making as a result. Here, we unpack how these three themes became interwoven to endow the commission from day one with a very particular focus on climate change mitigation strategies and the attainment of a net zero emissions status for the city.

While both mitigation and adaptation are given credence in the aspirations of the wider PCAN project, in Edinburgh climate mitigation emerged from a very early stage as the important agenda for those setting up the Commission. The dominance of this narrative was catalysed by a particular type of analysis which predates the PCAN project: the Mini Stern Review, which presents a city-scale emissions profile, breaking down mitigation strategies by economic sectors, and delivering a roadmap to the neutralisation of emissions within these sectors in the future. This idea is based on the UK national Stern Review (Stern, 2006) and has been led by researchers from the University of Leeds whose success in producing a Mini Stern Review for the city of Bristol was a key catalyst for the development of similar review for Leeds, Belfast and Edinburgh. These reviews and their identification of 'cost-effective' emission reduction options, have helped shape discussions within each of the PCAN cities, offering a boundary object for intercity dialogue and stakeholder engagement. As a consequence, the City of Edinburgh's adopted target of net zero by 2030 became a central structuring mechanism in establishing the relationship between the council, the university and, ultimately, the commission.

A quantification of a city's carbon footprint is a growing trend in urban climate governance where the socio-natural complexities of climate change are represented by economic sectors or types of infrastructure 
and their respective climate impacts (Rice, 2014). This trend has been accelerated by a growing number of citybased emissions targets which have emerged as a symptom of a more autonomous, and competitive regime of urban climate governance. Often set by local governments in the aftermath of emergency declarations (Rode, 2019), while regularly accompanied by strategy documents attempting to describe how these net zero goals will be achieved, previous research has highlighted the ways in which these agendas can result in profound forms of urban depoliticization; "[t]ranslat[ing] potentially interesting dynamics into a consensual project for urban renewal and city marketing" (Kenis \& Lievens, 2017 , p. 1762). This depoliticization of potentially disruptive, agentic cities and their populations has been framed by numerous scholars as a form of technocratic sustainability 'fix,' allowing for an engagement with climate change that is palatable for the existing (and dominant) political economy (Dujardin, 2020; Karaliotas \& Bettini, 2016; Nciri \& Levenda, 2019).

In Edinburgh, this depoliticization took a number of forms and a number of concerns were raised as to the viability and validity of the city's Mini Stern review; both by members of the project team at the University and by commissioners during the recruitment process. In the first instance this review was criticized for being misleading by virtue of claiming that a 2030 net zero target could be achieved by offsetting emissions outside of the city boundaries while strategically neglecting to include scope three emissions (emissions intimately connected to the city and its constituents but released outside of city boundaries) in these calculations. Furthermore, the analysis was seen as unethical for how it approached the setting of a carbon budget for Edinburgh, simply dividing the IPCC's global budget by total population without recourse to the burden of responsibilities for taking action. Precisely as Kenis and Lievens (2017) warn, a very particular (and literal) interpretation of the geography of the city is inscribed in order to justify the setting of an achievable net zero goal without debate over the practical and or ethical implications of this feasibility. Beyond this, and perhaps most importantly, a readily transferable methodology for emissions profiling on the part of PCAN, and a city council with a recently adopted (and notably ambitious) net zero target served to sideline opportunities for alternative, more nuanced forms of both intra-city and inter-city knowledge sharing.

Even though, as argued by Wesselink and Gouldson (2014), these Mini Stern reviews are not intended to be used 'instrumentally,' the timing of the adoption of this report in the Edinburgh context offered a particular interpretation of how the Climate Commission could establish legitimacy vis-a-vis the city's newly adopted net zero-strategy. This raises questions about the impact that both the speed at which the Commission was set up, and the need for political and institutional legitimacy, would have on democratic and geographical accountability in commissioner selection and recruitment. In princi- ple, aspirations to establish a new institution (rather than merely deliver a strategy document) offered Edinburgh an opportunity to 're-politicise' climate change in the wake of net zero goal setting (Kenis \& Lievens, 2017). In practice, however, an opportunity to avoid becoming "embroiled in the politics" (EdU2) justified the commission's focus on already adopted council emissions targets as its principle priority. As a result, and as the quote at the start of this section indicates, this rush to "get on with it" became a key feature of setting up the Commission; something echoed during other interviews:

And we were conscious that we wanted to move quite quickly and get things up and running. And if we could, we wanted to be able to kind of populate the Commission without having to go to any kind of competitive advertising process of recruiting people. (EdCC)

Practices of carbon measurement and accounting provide key tools through which power is exercised over an urban landscape "where carbon's calculability plays a central role in defining the targets of urban planning and the moulding of urban environmental citizenship" (Rice, 2014, p. 385). While not in itself a negative practice, when taken in isolation this focus on what Hulme (2019) terms "hitting the carbon numbers," i.e., achieving a reduction in emissions as fast as possible, prevents the city from being looked at with a broader lens. As Hulme (2019, p. 24) expands: "[a]cting under conditions of climate emergency to do 'whatever it takes' risks marginalising a wider set of justice and well-being concerns." Consequently, in setting up the Commission, discussions around intersectionality and relationality rarely managed to penetrate the barriers of senior decisionmaking processes which remained occupied by bureaucratic challenges of implementation and focused on the issue of emissions and the looming narrative of a climate emergency:

I certainly didn't see the Commission being made up of representatives of Edinburgh with people from different geographies in Edinburgh, different backgrounds, different professional backgrounds, different ages, different ethnic backgrounds, because the Commission is not a body designed to kind of reflect the diversity of Edinburgh it's a body designed to reflect the diversity of voices that are needed in order to best articulate the approach to tackling climate change. (EdCC)

Implied here is the idea that the people deemed best able to articulate the challenges and solutions to climate change in the city are those with technocratic expertise. This attitude excludes a diversity of knowledges and perpetuates the idea of climate change as a two-dimensional 'problem' for which we require expert, technocratic solutions (Dujardin, 2020). As famous urban 
theorist Jane Jacobs (1961, p. 17) wrote: "As in all Utopias, the right to have plans of any significance belonged only to the planners in charge." Building on this, there was a sense from senior stakeholders that questions of demographic representation would be better addressed in later iterations of the Commission. Ironically, given that in political terms 2030 remains a considerable time in the future, for those involved in setting up the commission, what came to matter most was the here and the now. In the following section we therefore open up the question of how this urgency translated into a specific set of individuals ultimately chosen to represent the city, and the form of collective agency sought by bringing them to the table.

\subsection{Representing a Climate Changing Edinburgh}

We talked about different ways of doing this, from having lay people on the Commission being dependent on expertise from outside...to having the kind of Commission we've ended up with, which is a combination of cross cutting expertise on different issues and deep sectoral expertise.... I was also keen to make sure that the Commission was gender balanced, which I'm pretty sure we've achieved and that there was also a bit of an age demographic kind of representation across the Commission as well. You know, it had to cover the key sectors that were going to be critical in driving down emissions. (EdCC)

Across the UK, cities are increasingly engaged in climate governance. Often made manifest through emission targets and sustainability plans, this localised approach is unfolding in a fractured urban governance landscape where it is unclear who should be responsible for climate change as a governance issue (Barron et al., 2020; Hughes et al., 2018; Vallance et al., 2019). It is out of this landscape that the PCAN network's Climate Commissions have emerged and, given the growing awareness of the need to encourage collaboration, the responsibility of choosing which people from across this diverse and complex city to bring together, became a key part of setting up the Edinburgh Commission.

Driven, in no small part, by the way in which the city's emission profile was characterised by sector in the Mini Stern review, the shortlisting process for commissioners, led by the secretariat at the University, placed significant emphasis on representing these sectors on the Commission. To catalyse the required action, engaging with what were often referred to as 'the right people,' was a key element for many. When asked to expand on this during interviews, an ability to directly or indirectly mobilise financial capital or other assets in pursuit of technological and behavioural change was identified as a key factor. As the extracts below highlight, it was important for those drawing up the shortlist to select candidates who worked within an influential industry, had knowledge of sustainability and also wielded enough social capital to be able to effectively disseminate messages across and between communities:

I think we are going for relatively large organisations because there's a bit of looking for people who have influence, expertise, and, you know, time to give to a Commission. (EdU3)

If the Climate Commission is going to advise us and be able to wield some power to make things happen, it needs to have expertise on it. But it will also need to have people from the various sectors who are respected by those sectors and understand those sectors. (EdCouncil2)

The problem is you need the clout, you need the backing of the CEO. But you also need the knowledge and the expertise of people who are actually doing it. (EdCouncil1)

From these extracts it is clear that access to both financial and social influence were key elements to commissioner selection alongside a degree of expertise on climate change. There was a sense in these discussions that by engaging powerful 'experts' (particularly those from the private sector), the position of the Commission would be seen as more legitimate in the city and that there would be a greater chance of it catalysing action in what were otherwise regarded as hard to reach industries. Beyond these factors, as the extract at the start of this section indicates, there was also a commitment to achieving a gender balance which became a prominent point of discussion (at times contention) during the setup process. The challenge of realising this commitment was described by EdU1:

I think if we go with the criteria, I definitely think it would be good to have a woman Chair but the most important thing for the success of the Commission is to have the person who is the best qualified with the best ties...the thing that was most difficult...was to find a woman in the private sector with a background in climate.

Gender is often regarded as a low hanging fruit when it comes to demographic diversity and, in the case of the Edinburgh Commission, gender was consciously considered in the selection of commissioners. However, the internal debate highlighted here, and the eventual choice of a male Chair, indicates that social standing and power within a particular sector became more important than securing a female lead. This failure to appoint a female Chair was again justified on the ground of finding the 'right person,' something which was seen to trump "tokenistic reasons" (personal communication, City Council officer).

These extracts show that selecting individuals with existing power and influence became a driving force in 
Commission development and one that, in some cases, trumped the inclusion of basic levels of demographic diversity. With this in mind, the recruitment of these individuals became an important and interesting part of the Commission's story. Rather than use an external application process, commissioners were identified either by their public profiles (such as Linkedln, a route to professional profiles and characteristics) or connections with stakeholders, and were approached individually. At one point this selection process consisted of an initial list of potential commissioners being passed around the secretariat team who then added to it based on their own connections with people in the city-region. While offering a degree of variation and access to a certain set of personal networks within the area of climate change, this means of selection limited engagement with the wider city to personal, fairly homogenous and socially elite networks.

This use of personal networks is illustrated by EdU3:

The clout that you get from that and then access to resource like my friend's dad, I put him down because I think he's a really great guy. And he's, I think Chairman of a Development firm with offices in Edinburgh.

Because I sort of knew what they were looking for, at that point: people from big law firms or people from big companies, it was kind of easy to sift through....And then obviously, the environment sector....Edinburgh is quite a small city so people do know each other, people have worked with each other before.

While this informal method of selection certainly restricts the pool of potential commissioners, it does grant a degree of pre-ordained cohesion to the Commission as members have common goals. There was also a sense that this process of mobilising social networks was faster and more efficient than using applications to create a pool of commissioners, something that, as we have seen, was important to stakeholders developing the Commission.

Since the global economic crash of 2008 there has been a growing prevalence of narratives around community 'resilience' within UK policy (Walker \& Cooper, 2011). This reflects a wider trend of austerity and neoliberal agenda setting as local governments become further reduced in their ability to deliver services and, as a result, devolve responsibility to citizens. With this in mind there is certainly merit in devolving this responsibility to more robust (and culpable) actors rather than putting pressure on already under-resourced communities. On this subject, one interviewee highlighted the role of privileged groups in both addressing climate change and in facilitating the inclusion of less powerful voices without placing the burden of responsibility on them:

We do absolutely need their voices, but people have chaotic lives, and they're living in deprivation and poverty. They don't have time to care about other people and all of those things. Their priorities are looking after themselves. So, our expectations of how they engage is different. I think it's more important to help them get to where they need to be in order to be able to engage. (EdCouncil1)

This insight speaks to the complex issue of representational justice and the importance of being able to accommodate a range of voices and perspectives without adding to financial or emotional burdens. This is important to bear in mind as, in order to co-produce Place Based Leadership, actors and organisations must have sufficient 'slack' resources (such as time, money and energy) to contribute to the governance of place (Beer \& Clower, 2014). In Edinburgh, this meant that many people have been unable to take part in emergent forms of Place Based Leadership, a fact that extends not only to under-represented communities but even to some of the selected Commissioners who are sometimes juggling multiple high-pressure jobs. By (understandably) aligning its workplan with existing council visions and strategies in order to achieve legitimate institutional authority rapidly, the recruitment narrative quickly become one of what commissioners could do for the Commission and its agenda, rather than what a new climate commission might do for them as diverse representatives of the city, and, by extension, for the city as a place:

Something about this meeting feels like a kickoff, like we can go off and be leaders in our communities and professional networks from today...to actually harness that agency within our communities in Edinburgh....and try to drive some of these behaviour changes that people are willing to engage with. But it's not just about what we want them to do but about finding out what they are doing because we have an incredible city and there are lots of things being mobilised at the moment with the Covid-19 response but also that have been going for a long time...so for me I feel like I want to liberate that agency right from today and use the influence that each of us has as commissioners and leaders. (A Commissioner during the first Commission meeting, March 2020)

Despite considerable emphasis being based on emissions reduction and the city's net zero goal in both the conceptualisation of the commission's role and the recruitment of commissioners (or perhaps precisely because of), there had been a desire to include in the selection, a representative from "the community" (EdU2). The long quote above, from the commissioner appointed to play this role, comes from the first climate commission meeting in March 2020. In stark contrast to the top-down approach to commissioner recruitment, this offered hope for driving bottom-up agency, connecting together a fragmented, complex and messy city when it comes to the issue of climate change 
governance. In doing so, however, it also raised key analytical questions (engaged with by this article's analysis) about how this agency is embodied and enacted by other commissioners. Commissioners who were recruited not for their embeddedness in place and the communities that they (too) represent, but for their respective areas of expertise with regards to direct action on climate change.

Building on the conceptualisation of place in the previous section, this section has unpacked the question of who was chosen to represent this way of understanding the city. Reflecting on what this means for climate change and democracy at the city scale, it is clear from this analysis that selecting known individuals who possessed not only technical expertise but also social power, was a primary focus for University and Council stakeholders when selecting commissioners. Questions of demographic diversity, beyond that of a gender balance, were not seen as an important element in this process which took place predominantly through the personal and professional networks of stakeholders involved in setting up the Commission. These observations point to the challenge of building diverse coalitions as it relies primarily on the unpaid labour of stakeholders thus excluding the experiences of under-resourced communities. This arguably stems from a lack of opportunity to recognise (and subsequently act upon) the fact that the very challenges facing such communities, which would supposedly limit their ability to participate in discussions on climate change, are likely to be interwoven with the very same social, political and economic forces at the heart of unsustainable emissions levels.

\section{Concluding Discussion}

The focus of this article has been the question of how place-based climate commissions as experimental forms of urban climate governance strive to represent the cities whose future's they hope to shape. Drawing on ethnographic research methods to explore how the city has been both conceptualised and represented as a 'place' through the Commission's establishment, we have illustrated how what these institutions are charged with doing (and the need for this to be tangible and orientated on impact in the short term) comes to frame what they will be vis-à-vis existing urban climate politics. More specifically, our critical reflections have shown that a fast-tracked conceptualisation of place, instigated from the top-down and structured by the extra-local nature of the PCAN project and its weddedness to the value of emission reduction strategies based on sectoral analysis, has legitimised a focus on technocratic, 'expert' knowledge, capable of delivering measurable impacts. In doing so however, it became difficult to encourage a move beyond this static and abstract performance of Edinburgh and towards a more relational interpretation of place (Massey, 2004), one which takes seriously the importance of building a diverse ecology of rele- vant, place-based, knowledges about the city's (and the planet's) future (Santos, 2008).

Reflecting on these findings, we are compelled to ask ourselves; what is insufficient about existing forms of urban representation when addressing climate change as a place-based governance issue? Have we fully considered why climate change requires special status in this regard, or indeed the implications for urban democracy of granting this status? Our arrival at these questions is borne out of the article's threefold contribution to the existing literature on urban climate governance. Firstly, we provide evidence that the depoliticization of climate change as a governance issue, associated with the setting of net zero goals and associated decarbonisation roadmaps (Kenis \& Lievens, 2017) is capable of taking an institutional form in how it can be used to justify the role and purpose of climate commissions. Secondly, we have documented how a pressure and need to deliver things at pace in light of the pressing nature of the climate challenge can be drawn upon as justification for accepting this depoliticization of the challenge. Third and finally, we have demonstrated how active aspirations to be involved with place-based climate governance inevitably require the establishment of a new structure that is institutionally 'tangible' and visible from the outset. This is as opposed to working with and seeking to coordinate and amplify the diverse, complex and explicitly political agencies that already exist within and through the city (Castán Broto, 2020; Ramirez et al., 2020).

With not only democratic legitimacy but also a wealth of local knowledge, the local political sphere continues to hold a pivotal, yet often undervalued and under-resourced, role within governance. For this reason, rather than Commissions needing to be a new, independent form of governance, perhaps there is an opportunity to approach this institutional resource as a vehicle for re-energising climate change politics within the city? Much like the role played by politically 'green' parties described in Robert Goodin's (1992) book Green Political Theory, capable of catalysing great change by influencing the policies of existing parties, there is an opportunity for Commissions to work closely with existing local democratic frameworks and their associated geographies. Commissions could be more than a 'critical friend' holding already existent local government policy to account (as the Commission's role in the city is regularly represented). Instead, they might be a platform to catalyse institutional innovation, empower stakeholders and build situated climate knowledges within the city. Rather than feeding the zero-sum game of carving out resources from existing local allocations, there is an opportunity to unlock new resources and possibilities.

The anecdotal reflection from the Commission presented at the close of the previous section offers great hope as to what climate commissions might be or might become with regards to harnessing and amplifying the place-based agency of the city in the fight against climate change. The challenge for cities like Edinburgh, 
embedded within wider inter-city networks of placebased action, is to avoid missing these opportunities by simply writing them off as incompatible with preconceptualised definitions of what constitutes 'placebased' climate action (and what it should strive to achieve). Thus far an interpretation of 'place' has been transposed upon the city in the understandable rush to prioritise tackling planetary scale issues such as climate change by privileging the 'local,' without sufficient recourse to what this actually means beyond mere location (Massey, 2004; Russell, 2019). Even 'Mini Stern,' the informal name given to the techno-managerial review outlining a cost-effective roadmap to net zero, speaks to the local as merely a sub-unit of the national scale. A scale down to which existing sustainability 'fixes,' wellrehearsed by national government, should be dropped (Nciri \& Levenda, 2019). Inter-city climate action initiatives such as PCAN must strive to find ways to balance the vital networking and learning opportunities they facilitate with resisting a one-dimensional and static interpretation of the 'places' that they seek to network together. Failure to do so risks diminishing the unique dynamism and creativity of cities

\section{Acknowledgments}

We thank all the research participants and gratefully acknowledge funding received from the UK's Economics and Social Sciences Research council (ESRC) through the PCAN (P-CAN; Ref. ES/S008381/1).

\section{Conflict of Interests}

The authors declare no conflict of interests.

\section{References}

Allen, M. (2017). The SAGE encyclopaedia of communication research methods (Vols. 1-4). Thousand Oaks, CA: SAGE Publications.

Anguelovski, I., \& Carmin, J. (2011). Something borrowed, everything new: Innovation and institutionalization in urban climate governance. Current Opinion in Environmental Sustainability, 3(3), 169-175.

Barron, E., Hartman, L., \& Hagemann, F. (2020). From place to emplacement: The scalar politics of sustainability. Local Environment, 25(6), 447-462.

Beer, A., \& Clower, T. (2014). Mobilizing leadership in cities and regions. Regional Science, 1(1), 5-20.

Braun, B. (2002). The intemperate rainforest: Nature, culture, and power on Canada's west coast. Minneapolis, MN: University of Minnesota Press.

Caprotti, F., \& Cowley, R. (2017). Interrogating urban experiments. Urban Geography, 38(9), 1441-1450.

Castán Broto, V. (2020). Climate change politics and the urban contexts of messy governmentalities. Territory, Politics, Governance, 8(2), 241-258.

Cleaver, F. D., \& de Koning, J. (2015). Furthering criti- cal institutionalism. International Journal of the Commons, 9(1), 1-18.

Davidson, M., \& Iveson, K. (2015). Recovering the politics of the city: From the 'post-political city' to a 'method of equality' for critical urban geography. Progress in Human Geography, 39(5), 543-559.

Dikeç, M., \& Swyngedouw, E. (2017). Theorizing the politicizing city. International Journal of Urban and Regional Research, 41, 1-18.

Dujardin, S. (2020). Planning with climate change? A poststructuralist approach to climate change adaptation. Annals of the American Association of Geographers, 110(4), 1059-1074.

Emerson, R. M., Fretz, R. I., \& Shaw, L. L. (2011). Writing ethnographic fieldnotes. Chicago, IL: University of Chicago Press.

Flyvbjerg, B. (2006). Five misunderstandings about casestudy research. Qualitative Inquiry, 12(2), 219-245.

Flyvbjerg, B. (2011). Case study. In K. Norman, K. Denzin, \& Y. S. Lincoln (Eds.), The Sage handbook of qualitative research (pp. 301-316). Thousand Oaks, CA: Sage.

Fudge, S., \& Peters, M. (2009). Motivating carbon reduction in the UK: The role of local government as an agent of social change. Journal of Integrative Environmental Sciences, 6(2), 103-120.

Goodin, R. (1992). Green political theory. Cambridge: Polity Press.

Hammersley, M., \& Atkinson, P. (1983). Ethnography: Principles in practice. London: Tavistock.

Harvey, D. (1989). From managerialism to entrepreneurialism. Geografiska Annaler, 71, 3-17.

Hodson, M., \& Marvin, S. (2010). Urbanism in the Anthropocene: Ecological urbanism or premium ecological enclaves? City, 14, 298-313.

Hughes, S., Chu, E., \& Mason, S. (2018). Climate change in cities: Innovations in multi-level governance. Cham: Springer International Publishing.

Hulme, M. (2019). Climate emergency politics is dangerous. Issues in Science and Technology, 36(1), 23-25.

Jacobs, J. (1961). The death and life of great American cities. New York, NY: Random House.

Jacobsen, A. J. (2014). Vignettes of interviews to enhance an ethnographic account. Ethnography and Education, 9(1), 35-50.

Jordan, A. J., Huitema, D., Hildén, M., Van Asselt, H., Rayner, T. J., Schoenefeld, J. J., . . . Boasson, E. L. (2015). Emergence of polycentric climate governance and its future prospects. Nature Climate Change, 5(11), 977-982.

Karaliotas, L., \& Bettini, G. (2016). Urban resilience, the local and the politics of the Anthropocene: Reflections on the future of the urban environment. In K. Archer \& K. Bezdency (Eds.), Handbook of cities and the environment (pp. 65-84). Cheltenham: Edward Elgar Publishing Ltd.

Kenis, A., \& Lievens, M. (2017). Imagining the carbon neutral city: The (post) politics of time and space. Envi- 
ronment and Planning A: Economy and Space, 49(8), 1762-1778.

Mannay, D., \& Morgan, M. (2015). Doing ethnography or applying a qualitative technique? Reflections from the 'waiting field.' Qualitative Research, 15(2), 166-182.

Massey, D. (2004). Geographies of responsibility. Geografiska Annaler, 86(1), 5-18.

Mouffe, C. (2005). On the political. London: Routledge.

Nciri, A., \& Levenda, A. (2019). Urban policy (im) mobilities and refractory policy lessons: experimenting with the sustainability fix. Urban Geography, 41(9), $1-21$.

Pachirat, T. (2017). Among wolves: Ethnography and the immersive study of power. London: Routledge.

Place-Based Climate Action Network. (2019). What is a local climate commission? PCAN. Retrieved from https://pcancities.org.uk/what-local-climatecommission

Quijano, A. (2000). Coloniality of power and Eurocentrism in Latin America. International Sociology, 15(2), 215-232.

Ramirez, M., Estevez, J. H. G., Goyeneche, O. Y. R., \& Rodriguez, C. E. O. (2020). Fostering place-based coalitions between social movements and science for sustainable urban environments: A case of embedded agency.' Environment and Planning C: Politics and Space, 38(7/8), 1386-1411.

Rice, J. (2014). An urban political ecology of climate change governance. Geography Compass, 8 , 381-394.

Rode, P. (2019). Climate emergency and cities: An urban-led mobilisation? The Climate Decade's priorities for urban climate action, policy and research. London: LSE Cities. Retrieved from https://Isecities. net/wp-content/uploads/2019/10/Rode-P-2019-

Climate-Emergency-and-Cities-An-urban-ledmobilisation.pdf

Romero-Lankao, P., Bulkeley, H., Pelling, M., Burch, S., Gordon, D., Gupta, J., . . . Munshi, D. (2018). Urban transformative potential in a changing climate. Nature Climate Change, 8, 754-756.
Russell, B. (2019). Beyond the local trap: New municipalism and the rise of the fearless cities. Antipode, 51(3), 989-1010.

Santos, B. (2008). Introduction: Opening up the canon of knowledge and recognition of difference. In B. Santos (Eds.), Another knowledge is possible: Beyond northern epistemologies (pp. xix-Ixii). London: Verso.

Spradley, P. (1980). Participant observation. Long Grove, IL: Waveland Press.

Stern, N. (2006). Stern Review on the economics of climate change: Executive summary. London: HM Treasury.

Stripple, J., \& Bulkeley, H. (2019). Towards a material politics of socio-technical transitions: Navigating decarbonisation pathways in Malmö. Political Geography, $72,52-63$.

Vainer, C. (2014). Disseminating 'best practice'? In S. Parnell \& S. Oldfield (Eds.), The Routledge handbook on cities of the global south (pp. 48-56). London: Routledge Handbooks Online.

Vallance, P., Tewdwr-Jones, M., \& Kempton, L. (2019). Facilitating spaces for place-based leadership in centralized governance systems: The case of Newcastle City Futures. Regional Studies, 53(12), 1723-1733.

Van Maanen, J. (2011). Tales of the field: On writing ethnography. Chicago, IL: University of Chicago Press.

Walker, J., \& Cooper, M. (2011). Genealogies of resilience: From systems ecology to the political economy of crisis adaptation. Security Dialogue, 42(2), 143-160.

Ward, K. (2018). Urban redevelopment policies on the move: Rethinking the geographies of comparison, exchange and learning. International Journal of Urban and Regional Research, 42(4), 666-683.

Webb, J. (2019). New lamps for old: Financialised governance of cities and clean energy. Journal of Cultural Economy, 12(4), 286-298.

Wesselink, A., \& Gouldson, A. (2014). Pathways to impact in local government: The Mini Stern review as evidence in policy making in the Leeds City Region. Policy Sciences, 47, 403-424.

\section{About the Authors}

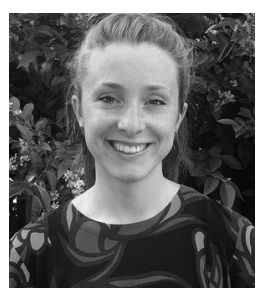

Alice Creasy is a Research Assistant at the Edinburgh Climate Change Institute focusing on issue of urban environmental governance. Alongside her work at the Edinburgh Climate Change Institute, she is a Policy and Membership Officer for the Local Government Information Unit and is a Co-Founder of the Embra Collective, an intersectional feminist collective that focuses on issues of climate change and sustainability. Alice has a first-class degree in Geography from the University of Glasgow and has recently graduated with distinction from an MSc in Environmental Sustainability at the University of Edinburgh.

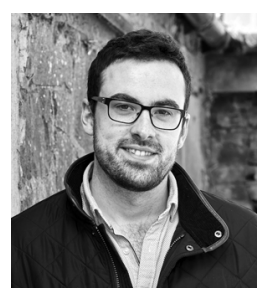

Matthew Lane is a Postdoctoral Research Fellow at the University of Edinburgh School of Geosciences and a Researcher in Sustainable Urban Governance. He is interested in how city and regional governments are coping with an increased responsibility to act on crises of sustainability despite having limited legal, institutional, political and economic capacity to do so. He has undertaken ethnographic fieldwork in the UK, Zambia, China and the United States of America. 


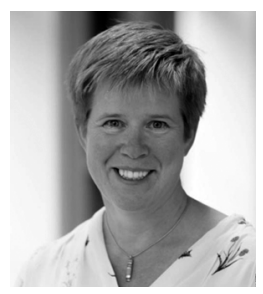

Alice Owen is a Professor in Business, Sustainability and Stakeholder Engagement at the University of Leeds. An Engineer by training Alice's career has spanned private, public and voluntary sector organisations and she has a track record of achievement in developing and delivering projects to support more sustainable development. After completing her PhD in 2013, Alice joined the Sustainability Research institute at the University of Leeds. Alice is actively involved in several place-based climate action organisations.

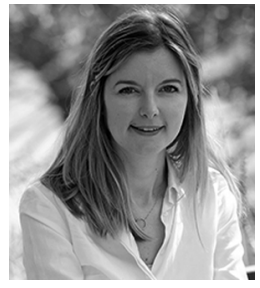

Candice Howarth is a Senior Policy Fellow at the Grantham Research Institute on Climate Change and the Environment leading the PCAN activities. She also leads broader research on how the co-production of knowledge and science communication can be used to better inform decision making in the context of climate resilience and sustainability challenges. She Chairs the Royal Geographical Society Climate Change Research Group, sits on the Royal Meteorological Society Climate Engagement Communication group, and the London Heat Risk Group. She is a Contributing Author to the Third UK Climate Change Risk Assessment (CCRA3) and sits on the Editorial Board of the journal Environmental Communication.

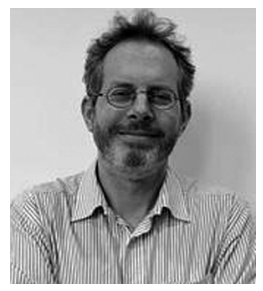

Dan van der Horst is a Professor in Environment, Energy and Society. Focusing on scarce resources in crowded spaces, his interests include the governance of multifunctionality and shared value, and the tools, practices and politics of resource allocation and conflict management, especially in the context of energy transitions, the deployment of clean technologies and the designation of land for development or conservation. 